\title{
ANALISIS KESALAHAN PENGGUNAAN EJAAN DALAM KARANGAN NARASI SISWA KELAS X SMA SWASTA TAMAN SISWA BINJAI TAHUN PEMBELAJARAN 2016/2017
}

\author{
Oleh \\ Nurul Fajarya \\ Drs. Azhar Umar, M.Pd.
}

Penelitian ini bertujuan untuk mendeskripsikan dan mengklasifikasikan bentuk kesalahan penggunaan ejaan yang terdapat dalam karangan narasi siswa kelas X SMA Swasta Taman Siswa Binjai tahun pembelajaran 2016/2017, mendeskripsikan kesalahan ejaan yang paling dominan dilakukan siswa dalam karangan narasi yang diproduksi tersebut. Penelitian ini menggunakan pendekatan deskriptif kualitatif. Hasil penelitian ini adalah sebagai berikut. Pertama, Jumlah kesalahan penggunaan ejaan yang terdapat dalam karangan siswa mencapai $945(17,67 \%)$ kesalahan dari 5.349 ejaan yang seharusnya diproduksi. Bentuk kesalahan ejaan dibedakan menjadi enam aspek, yaitu kesalahan pada tataran penggunaan huruf kapital, penggunaan kata berimbuhan, penggunaan kata depan, penggunaan unsur serapan, penggunaan tanda baca titik, dan penggunaan tanda baca koma. Dari keenam aspek tersebut ditemukan 570 $(48,76 \%)$ kesalahan penggunaan huruf kapital, 101 (6,33\%) kesalahan penggunaan kata berimbuhan, $83(31,20 \%)$ kesalahan penggunaan kata depan, $63(6,16 \%)$ kesalahan penggunaan unsur serapan, $27(3,57 \%)$ kesalahan penggunaan tanda baca titik, dan $101(18,70 \%)$ kesalahan penggunaan tanda baca koma. Kedua, Dari persentasi kesalahan tersebut, kesalahan pada tataran penggunaan huruf kapital merupakan kesalahan yang paling dominan dilakukan oleh siswa, yaitu mencapai 570 (48,76\%) kesalahan dari 1.169 huruf kapital yang seharusnya diproduksi. Selanjutnya, kesalahan yang paling sedikit terjadi adalah kesalahan penggunaan tanda baca titik yang mencapai $27(3,57 \%)$ kesalahan dari 756 tanda baca titik yang seharusnya diproduksi.

Kata kunci: analisis kesalahan, ejaan, narasi

\section{PENDAHULUAN}

Menulis merupakan salah satu jenis pengaktualisasian bahasa dalam bentuk tulisan. Menulis adalah hal yang sangat penting untuk menyampaikan ide gagasan secara logis dalam proses pembelajaran di sekolah. Tetapi pada kenyataannya masih 
terdapat banyak kesalahan penggunaan ejaan dalam sebuah tulisan. Kesalahan penggunaan ejaan merupakan salah satu masalah yang sering dilakukan siswa dalam menulis. Tanpa menguasai ejaan siswa tidak mampu menulis dengan baik dan benar. Kesalahan-kesalahan tersebut dapat diketahui melalui proses analisis kesalahan yang merupakan suatu prosedur kerja yang digunakan untuk mengetahui seperti apa kesalahan-kesalahan yang dilakukan oleh siswa dalam menulis sebuah karangan. Hal ini sejalan dengan pendapat Ellis (dalam Tarigan, 2011: 60-61) menjelaskan bahwa analisis kesalahan adalah suatu prosedur kerja yang digunakan oleh para peneliti atau guru besar yang meliputi pengumpulan sampel, pengidentifikasian kesalahan yang terdapat dalam sampel, penjelasan dari kesalahan tersebut, pengklasifikasian kelasahan berdasarkan penyebabnya, serta pengevaluasian atau penilaian taraf keseriusan kesalahan itu. Selain itu, menurut Crystal (dalam Pateda, 1989: 32) analisis kesalahan adalah suatu teknik untuk mengidentifikasi, mengklasifikasikan, dan menginterpretasikan secara terstruktur kesalahan-kesalahan yang dibuat oleh siswa yang sedang belajar bahasa kedua atau bahasa bahasa asing.

Jadi, analisis kesalahan adalah suatu prosedur kegiatan mengidentifikai kesalahan lalu kesalahan tersebut di klasifikasikan berdasarkan penyebabnya serta mengevaluasi atau menilai taraf keseriusan kesalahan itu berdasarkan teori-teori dan prosedur-prosedur kebahasaan.

Tarigan (2011: 60) menyebutkan,

Analisis kesalahan mempunyai langkah-langkah yang meliputi:

1. Pengumpulan sampel,

2. Pengidentifikasian kesalahan,

3. Penjelasan kesalahan,

4. Pengklasifikasian kesalahan, dan

5. Pengevaluasian kesalahan

Selanjutnya, Tarigan (2011: 63-64) menyebutkan langkah-langkah kerja yang baru dari analisis kesalahan melalui penyeleksian, pengurutan, dan penggabungan, yaitu (1) mengumpulkan data, (2) mengidentifikasi dan mengklasifikasi kesalahan, (3) memperingkat kesalahan, (4) menjelaskan kesalahan, (5) memprakirakan atau memprediksi daerah atau hal kebahasaan yang rawan, dan (6) mengoreksi kesalahan. 
Analsisis kesalahan memiliki beberapa tujuan, yaitu: (1) untuk menentukan urutan penyajian hal-hal yang diajarkan di dalam kelas dan buku teks, (2) menentukan urutan jenjang relatif penekanan, penjelasan, dan latihan berbagai hal dari bahan yang diajarkan, (3) merencanakan latihan dan pengajaran remedial, dan (4) memilih hal yang cocok bagi pengujian kemahiran siswa.

Pada penelitian ini, yang menjadi titik fokus analisis adalah kesalahan penggunaan ejaan. Ejaan merupakan salah satu bentuk yang harus diperhatikan dalam menulis karena ejaan merupakan suatu kaidah atau ketentuan yang sudah ditetapkan dalam Bahasa Indonesia. Dalam Kamus Besar Bahasa Indonesia (Depdiknas, 2007) dijelaskan "Ejaan adalah kaidah-kaidah cara menggambarkan bunyi-bunyi (kata, kalimat, dan sebagainya) dalam bentuk tulisan (huruf-huruf) serta penggunaan tanda baca". Sedangkan menurut Barus ( 2010: 6) menjelaskan bahwa "Ejaan bahasa Indonesia adalah keseluruhan kaidah cara menggambarkan lambang-lambang bunyi bahasa dan bagaimana hubungan antara lambang-lambang itu (pemisahan, penggabungannya) dalam bahasa Indonesia". Oleh karena itu, sebuah tulisan akan dikatakan baik apabila menggunakan ejaan yang sesuai dengan ketentuan yang berlaku.

Ejaan yang digunakan dalam bahasa Indonesia saat ini dikenal dengan sebutan "Pedoman Umum Ejaan Bahasa Indonesia (PUEBI)". Ejaan ini ditetapkan pada tahun 2016, ejaan ini diterbitkan untuk menyempurnakan Ejaan Bahasa Indonesia yang Disempurnakan yang ditetapkan pada tahun 1972. Sebelum Ejaan yang Disempurnakan ditetapkan ada beberapa ejaan yang sudah ada seperti ejaan Ch. A. Van Ophuijsen (1901), ejaan Suwandi (1947), dan ejaan (1966). Tidak semua ejaan yang akan dibahasa dalam penelitin ini. Indikator ejaan pada penelitian ini adalah, (1) penulisan huruf kapital, (2) kata berimbuhan, (3) kata depan, (4) unsur serapan, (5) tanda baca titik, dan (6) tanda baca koma.

Selanjutnya, siswa sering melakukan kesalahan penggunakan ejaan pada karangan yang mereka kerjakan, karangan yang dimaksud adalah karangan narasi. Semi (1990: 32) menjelaskan "Narasi merupakan bentuk percakapan atau tulisan yang bertujuan menyampaikan atau menceritakan rangkaian peristiwa atau pengalaman manusia berdasarkan perkembangan dari waktu ke waktu”. Selain itu, menurut Keraf 
(2000: 136) "Narasi adalah suatu bentuk wacana yang sasaran utamanya adalah tindaktanduk yang dijalin dan dirangkaikan menjadi peristiwa yang terjadi dalam suatu kesatuan waktu". Penyebab dari seringnya siswa membuat kesalahan itu adalah ketika menulis karangan narasi siswa dituntut untuk menggunakan bahasa mereka sendiri, sehingga siswa seringkali lupa untuk menggunaan kaidah ejaan yang telah ditetapkan. Siswa seringkali terlalu asyik dalam mengarang tanpa menyadari bahwa terjadi banyak kesalahan ejaan yang tanda baca yang ada dalam karangan yang sedang di produksinya.

Dengan dilakukan analisis kesalahan penggunaan ejaan, dapat diketahui apa saja kesalahan ejaan yang sering dilakukan oleh siswa untuk membantu pengajar mengetahui sampai pada taraf apa pemahaman siswa terhadap ejaan. Selain itu, pengajar juga dapat memberikan pengajaran tentang ejaan secara lebih mendalam kepada siswa sebelum mereka ditugaskan untuk menulis sebuah karangan.

Berdasarkan uraian di atas, maka peneliti tertarik untuk melakukan penelitian tentang bagaimana kesalahan ejaan dalam karangan narasi siswa. Penelitian ini difokuskan pada (1) kesalahan penggunaan ejaan bahasa Indonesia di dalam karangan narasi siswa kelas X SMA Swasta Taman Siswa Binjai Tahun Pembelajaran 2016/2017, (2) Kesalahan ejaan yang dominan dilakukan siswa kelas X SMA Swasta Taman Siswa Binjai Tahun Pembelajaran 2016/2017 dalam membuat karangan narasi.

\section{METODE PENELITIAN}

Metode adalah jalan atau cara yang dilakukan seseorang untuk meraih atau mencapai suatu tujuan yang diinginkan. Metode penelitian merupakan suatu cara yang dilakukan dalam proses pemecahan masalah dengan mengumpulkan serta menganalisis data untuk mencapai suatu tujuan yang diinginkan. Dengan menggunakan metode penelitian maka sasaran dari penelitian yang dilakukan akan tercapai. Penelitian ini dilakukan dengan menggunakan metode deskriptif kualitatif. Alasannya karena penelitian ini menghasilkan data berupa kata-kata atau kalimat yang dapat menggambarkan atau mendeskripsikan suatu hal berupa kesalahan-kesalahan penggunaan ejaan yang dilakukan oleh siswa dalam menulis karangan narasi. 


\section{HASIL PENELITIAN DAN PEMBAHASAN}

\section{Hasil Penelitian}

\section{a. Deskripsi Data Kesalahan Penggunaan Ejaan}

\section{1) Deskripsi Data Kesalahan Penggunaan Huruf Kapital}

Berdasarkan hasil analisis kesalahan pada karangan narasi siswa kelas X SMA, terdapat $570(48,76 \%)$ kesalahan dari 1.169 huruf kapital yang seharusnya diproduksi. Kesalahan tersebut meliputi kesalahan pada penulisan huruf $\mathbf{a}, \mathbf{b}, \mathbf{c}, \mathbf{d}, \mathbf{e}, \mathbf{g}, \mathbf{h}, \mathbf{k}, \mathbf{l}, \mathbf{m}, \mathbf{n}$, $\mathbf{o}, \mathbf{r}, \mathbf{s}, \mathbf{t}, \mathbf{u}, \mathbf{w}, \mathbf{x}$, dan $\mathbf{y}$. Namun, kesalahan penulisan huruf kapital yang sering terjadi adalah huruf $\mathbf{l}, \mathbf{m}, \mathbf{a}, \mathbf{b}, \mathbf{t}, \mathbf{r}, \mathbf{c}$, dan $\mathbf{s}$. Kesalahan penggunaan huruf kapital merupakan kesalahan terbanyak yang dilakukan siswa dalam menulis karangan narasi.

\section{2) Deskripsi Data Kesalahan Penggunaan Kata Berimbuhan}

Berdasarkan hasil analisis kesalahan pada karangan narasi siswa kelas X SMA, terdapat $101(6,33 \%)$ kesalahan dari 1.596 kata berimbuhan yang seharusnya diproduksi. Kesalahan itu meliputi kesalahan pada penulisan awalan "di-, ke-, ber-, me-, mem-, se-, ter-, dan per-“. Lalu pada akhiran “-i, -an, dan -kan”. Namun, kesalahan imbuhan yang paling sering terjadi adalah pada awalan "di- dan ke-". Kesalahan penggunaan kata berimbuhan merupakan kesalahan terbanyak keempat yang terjadi dalam karangan narasi siswa.

\section{3) Deskripsi Data Kesalahan Penggunaan Kata Depan}

Berdasarkan hasil analisis kesalahan pada karangan narasi siswa kelas X SMA, terdapat $83(31,20 \%)$ kesalahan dari 266 kata depan yang seharusnya diproduksi. Kesalahan itu meliputi kesalahan kata “di dan ke". Namun, kesalahan kata depan yang paling sering terjadi terdapat pada kata “di". Kesalahan penggunaan kata depan merupakan kesalahan terbanyak kedua setelah kesalahan penggunaan huruf kapital yang terjadi dalam karangan narasi siswa. 


\section{4) Deskripsi Data Kesalahan Penggunaan Unsur Serapan}

Berdasarkan hasil analisis kesalahan pada karangan narasi siswa kelas X SMA, terdapat $63(6,16 \%)$ kesalahan dari 1.022 unsur serapan yang seharusnya diproduksi. Kesalahan-kesalahan itu meliputi penggunaan kata yang tidak baku. Kesalahan penggunaan unsur serapan merupakan kesalahan terbanyak kelima yang terjadi dalam karangan narasi siswa.

\section{5) Deskripsi Data Kesalahan Penggunaan Tanda Baca Titik}

Berdasarkan hasil analisis kesalahan pada karangan narasi siswa kelas X SMA, terdapat $27(3,57 \%)$ kesalahan dari 756 tanda baca titik yang seharusnya diproduksi. Kesalahan penggunaan tanda baca titik merupakan kesalahan yang paling sedikit terjadi dalam karangan narasi siswa.

\section{6) Deskripsi Data Kesalahan Penggunaan Tanda Baca Koma}

Berdasarkan hasil analisis kesalahan pada karangan narasi siswa kelas X SMA, terdapat $101(18,70 \%)$ kesalahan dari 540 tanda baca koma yang seharusnya diproduksi. Kesalahan penggunaan tanda baca koma merupakan kesalahan terbanyak ketiga terjadi dalam karangan narasi siswa.

\section{b. Kesalahan Ejaan yang Dominan Dilakukan}

Kesalahan penggunaan ejaan yang paling dominan terjadi dalam karangan narasi siswa kelas X SMA Swasta Taman Siswa Binjai terdapat pada kesalahan penggunaan huruf kapital yang mencapai $570(48,76 \%)$ kesalahan dari 1.169 huruf kapital yang seharusnya diproduksi. Setelah itu kesalahan yang paling sedikit terjadi dalam karangan narasi siswa kelas X SMA Swasta Taman Siswa Binjai adalah kesalahan penggunaan tanda baca titik yang mencapai 27 (3,57\%) kesalahan dari 756 tanda baca titik yang seharusnya diproduksi. 


\section{Pembahasan Hasil Penelitian}

\section{a. Kesalahan Penggunaan Ejaan}

\section{1) Kesalahan Penggunaan Huruf Kapital}

Kesalahan penggunaan huruf kapital yang ditemukan dalam karangan narasi siswa kelas X SMA Swasta Taman Siswa Binjai memiliki jumlah kesalahan sebanyak 570 kesalahan. Kesalahan penggunaan huruf kapital yang paling dominan adalah huruf $\mathbf{l}, \mathbf{m}, \mathbf{a}, \mathbf{b}, \mathbf{t}, \mathbf{r}, \mathbf{c}, \mathbf{d a n} \mathbf{s}$. kesalahan tersebut terjadi karena kurangnya pengetahuan siswa tentang kaidah penggunaan huruf kapital yang tepat, kurangnya perhatian siswa terhadap penjelasan dan contoh-contoh penulisan huruf kapital yang benar yang diberikan oleh guru bidang studi Bahasa Indonesia, dan kebiasaan buruk siswa yang sering meletakkan huruf kapital tidak pada tempatnya. Berdasarkan data tersebut, dapat diketahui bahwa kesalahan penggunaan huruf kapital merupakan kesalahan yang paling banyak terjadi dalam karangan narasi siswa kelas X SMA Swasta Taman Siswa Binjai.

\section{2) Kesalahan Penggunaan Kata Berimbuhan}

Kesalahan penggunaan kata berimbuhan yang ditemukan dalam karangan narasi siswa kelas X SMA Swasta Taman Siswa Binjai memiliki jumlah kesalahan sebanyak 101 kesalahan. Kesalahan penggunaan kata berimbuhan yang paling dominan terdapat pada imbuhan "di- dan ke-". Kesalahan itu terjadi karena siswa sering keliru membedakan kata "di- dan ke-“ yang merupakan imbuhan atau kata depan. Siswa seringkali memberikan jarak antara kedua kata tersebut dengan kata selanjutnya, padahal seharusnya jarak tersebut tidak diperlukan. Berdasarkan data tersebut, dapat diketahui bahwa kesalahan penggunaan kata berimbuhan merupakan kesalahan terbanyak keempat yang terjadi dalam karangan narasi siswa kelas X SMA Swasta Taman Siswa Binjai. 


\section{3) Kesalahan Penggunaan Kata Depan}

Kesalahan penggunaan kata depan yang ditemukan dalam karangan narasi siswa kelas X SMA Swasta Taman Siswa Binjai memiliki jumlah kesalahan sebanyak 83 kesalahan. Kesalahan penggunaan kata depan yang paling dominan terdapat pada kata "di“. Kesalahan itu terjadi karena siswa sering keliru membedakan kata tersebut yang merupakan imbuhan atau kata depan. Siswa seringkali tidak memberikan jarak antara kata tersebut dengan kata selanjutnya, padahal seharusnya jarak tersebut diperlukan. Berdasarkan data tersebut, dapat diketahui bahwa kesalahan penggunaan kata depan merupakan kesalahan terbanyak kedua setelah huruf kapital yang terjadi dalam karangan narasi siswa kelas X SMA Swasta Taman Siswa Binjai.

\section{4) Kesalahan Penggunaan Unsur Serapan}

Kesalahan penggunaan unsur serapan yang ditemukan dalam karangan narasi siswa kelas X SMA Swasta Taman Siswa Binjai memiliki jumlah kesalahan sebanyak 63 kesalahan. Kesalahan itu terjadi karena siswa kurang paham tentang kata serapan. Jadi, siswa seringkali menuliskan kata-kata tidak baku dalam karangan yang diproduksinya. Berdasarkan data tersebut, dapat diketahui bahwa kesalahan penggunaan unsur serapan merupakan kesalahan terbanyak kelima yang terjadi dalam karangan narasi siswa kelas X SMA Swasta Taman Siswa Binjai.

\section{5) KesalahanPenggunaan Tanda Baca Titik}

Kesalahan penggunaan tanda baca titik yang ditemukan dalam karangan narasi siswa kelas X SMA Swasta Taman Siswa Binjai memiliki jumlah kesalahan sebanyak 27 kesalahan. Kesalahan itu terjadi karena kurangnya kemampuan siswa dalam membedakan penggunaan tanda baca titik dengan tanda baca koma dan kurangnya pengetahuan siswa dalam menggunakan tanda baca titik. Sehingga, siswa seringkali menuliskan tanda baca koma, padahal yang seharusnya dituliskan adalah tanda baca titik. Berdasarkan data tersebut, dapat diketahui bahwa kesalahan penggunaan tanda baca titik merupakan kesalahan yang paling sedikit terjadi dalam karangan narasi siswa kelas X SMA Swasta Taman Siswa Binjai. 


\section{6) Kesalahan Penggunaan Tanda Baca Koma}

Kesalahan penggunaan tanda baca titik yang ditemukan dalam karangan narasi siswa kelas X SMA Swasta Taman Siswa Binjai memiliki jumlah kesalahan sebanyak 101 kesalahan. Kesalahan itu terjadi karena kurangnya kemampuan siswa dalam membedakan penggunaan tanda baca koma dengan tanda baca titik dan kurangnya pengetahuan siswa dalam menggunakan tanda baca koma. Sehingga, siswa seringkali menuliskan tanda baca titik, padahal yang seharusnya dituliskan adalah tanda baca koma. Berdasarkan data tersebut, dapat diketahui bahwa kesalahan penggunaan tanda baca koma merupakan kesalahan terbanyak ketiga yang terjadi dalam karangan narasi siswa kelas X SMA Swasta Taman Siswa Binjai.

\section{b. Kesalahan Ejaan yang Dominan Dilakukan}

Berdasarkan pembahasan penelitian di atas, dapat diketahui bahwa kesalahan penggunaan ejaan pada tataran penggunaan huruf kapital merupakan kesalahan yang paling dominan terjadi. Hal itu terjadi karena kurangnya pengetahuan siswa tentang kaidah penggunaan huruf kapital yang tepat, kurangnya perhatian siswa terhadap penjelasan dan contoh-contoh penulisan huruf kapital yang benar yang diberikan oleh guru bidang studi Bahasa Indonesia, dan kebiasaan buruk siswa yang sering meletakkan huruf kapital tidak pada tempatnya. Selanjutnya, kesalahan yang paling sedikit terjadi adalah kesalahan penggunaan tanda baca titik. Hal ini terjadi karena siswa sudah mampu meletakkan tanda baca titik yang sesuai dengan aturan dalam kaidah penggunaan ejaan. Walaupun, tetap saja ada siswa yang melakukan kesalahan penulisan tanda baca titik dalam karangan narasi yang di produksinya.

\section{PENUTUP}

Berdasarkan hasil temuan data dan pembahasan data penelitian mengenai analisis kesalahan penggunaan ejaan dalam karangan siswa kelas X SMA Swasta Taman Siswa Binjai dapat disimpulkan bahwa Jumlah kesalahan penggunaan ejaan 
yang terdapat dalam karangan siswa mencapai 945 (17,67\%) kesalahan dari 5.349 ejaan yang seharusnya diproduksi. Bentuk kesalahan ejaan dibedakan menjadi enam aspek, yaitu kesalahan pada tataran penggunaan huruf kapital, penggunaan kata berimbuhan, penggunaan kata depan, penggunaan unsur serapan, penggunaan tanda baca titik, dan penggunaan tanda baca koma. Dari keenam aspek tersebut ditemukan 48,76\% kesalahan penggunaan huruf kapital, 6,33\% kesalahan penggunaan kata berimbuhan, 31,20\% kesalahan penggunaan kata depan, 6,16\% kesalahan penggunaan unsur serapan, 3,57\% kesalahan penggunaan tanda baca titik, dan $18,70 \%$ kesalahan penggunaan tanda baca koma.

Dari persentasi kesalahan tersebut, kesalahan pada tataran penggunaan huruf kapital merupakan kesalahan yang paling dominan dilakukan oleh siswa, yaitu mencapai 570 (48,76\%) kesalahan dari 1.169 huruf kapital yang seharusnya diproduksi. Selanjutnya, kesalahan yang paling sedikit terjadi adalah kesalahan penggunaan tanda baca titik yang mencapai $27(3,57 \%)$ kesalahan dari 756 tanda baca titik yang seharusnya diproduksi.

\section{DAFTAR PUSTAKA}

Barus, Sanggup. 2010. Pembinaan Kompetensi Menulis. Medan: USU press.

Departemen Pendidikan Nasional. 2007. Kamus Besar bahasa Indonesia Edisi Ketiga. Jakarta: Balai Pustaka.

Keraf, Gorys. 2000. Argumentasi dan Narasi. Jakarta: PT Gramedia.

Pateda, Mansoer. 1989. Analisis Kesalahan. Flores: Nusa Indah.

Semi, M. Atar. 1990. Menulis Efektif. Padang: Angkasa Raya.

Tarigan, Henry Guntur dan Djago Tarigan. 2011. Pengajaran Analisis Kesalahan Berbahasa. Bandung: Angkasa Bandung.

Tim Pengembangan Pedoman Bahasa Indonesia. 2016. Pedoman Umum Ejaan Bahasa Indonesia. Jakarta: Badan Pengembangan dan Pembinaan Bahasa. 